\title{
Indsamling til Geologivognen - et projekt med overvaegt
}

Af Hans-Henrik Meyer formand for S.A.F.

Medlemmerne fra S.A.F. (Sydsjællands Amatørgeologiske Forening) var med, da der skulle indsamles materiale til Geologivognen.

I et indlæg i foreningens blad STUFE opfordrede formanden Hans-Henrik Meyer medlemmerne til en onsdag først $i$ januar at komme og donere bjergarter, fossiler og mineraler til Østsjællands Museums nyeste projekt Geologivognen. (Projektet er omtalt i Maja Hawthorns og Tove Damholts artikel side: 12 i blad 2/05))

Da dagen oprandt, var fremmødet af doneringsvillige medlemmer og deres samlede antal medbragte fund... imponerende. Da Maja Hawthorn desværre var blevet syg, kom Tove Damholt og Vagn Åge Andersen for at afhente det indsamlede materiale.

\section{Ønskeliste over sten}

I STUFE havde medlemmerne kunnet finde en liste, hvor de enkelte delområder i projektet var beskrevet samtidig med en "ønskeliste" over de sten, som projektet skulle indeholde.

Der var alt fra almindelige søpindsvin og belemnitter, basalter og porfyrer, kvartser og feldspatter til de mere sjældne stykker.

Selvfølgelig var der et par gengangere, men i betragtning af, at medlemmerne ikke på forhånd havde aftalt, hvem der tog hvad med, så var det samlede udbud utroligt mangeartet.

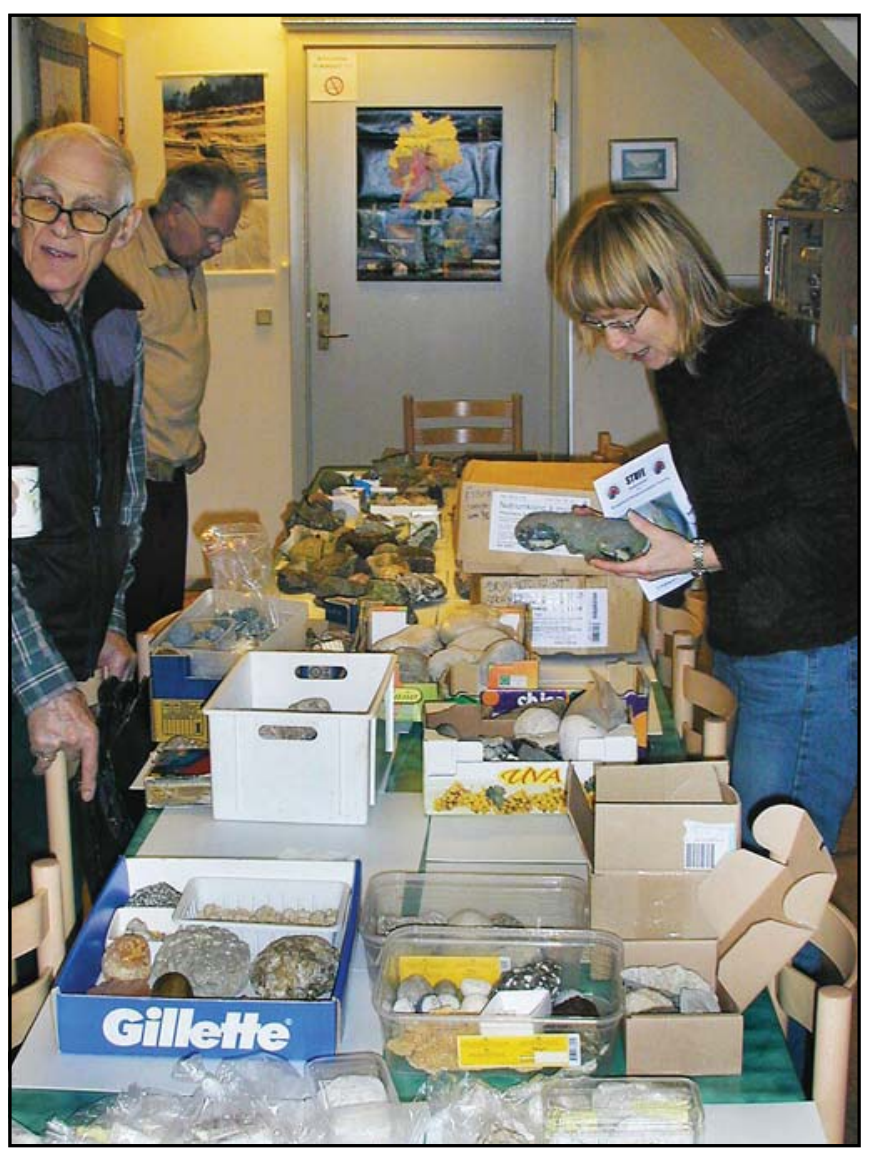

S.A.F.s klublokale.

(Foto: Niels Hansen)

S.A.F. havde også fået en aftale i hus om, at Østsjællands Museum kunne afhente forskelligt både råt og slebet materiale hos Næstved Flisecenter. (Sydsjællands største importør af bygnings- og belægningssten).

Større interesse for geologien Alle, der deltog, følte det var spændende som amatørgeolog at kunne bidrage med noget, der skulle bruges i museal og formidlingsmæssig sammenhæng og forhåbentlig på længere sigt vil kunne bibringe en større forståelse af og interesse for... geologien.

Vi håber at kunne præsentere Geologivognen på Stenmessen den 8. og 9. oktober 2005 i Næstved Hallen.

Tak til Østsjællands Museum for endnu et spændende samarbejde - og nu har vi alle plads til nogle nye fund i vores samlinger.

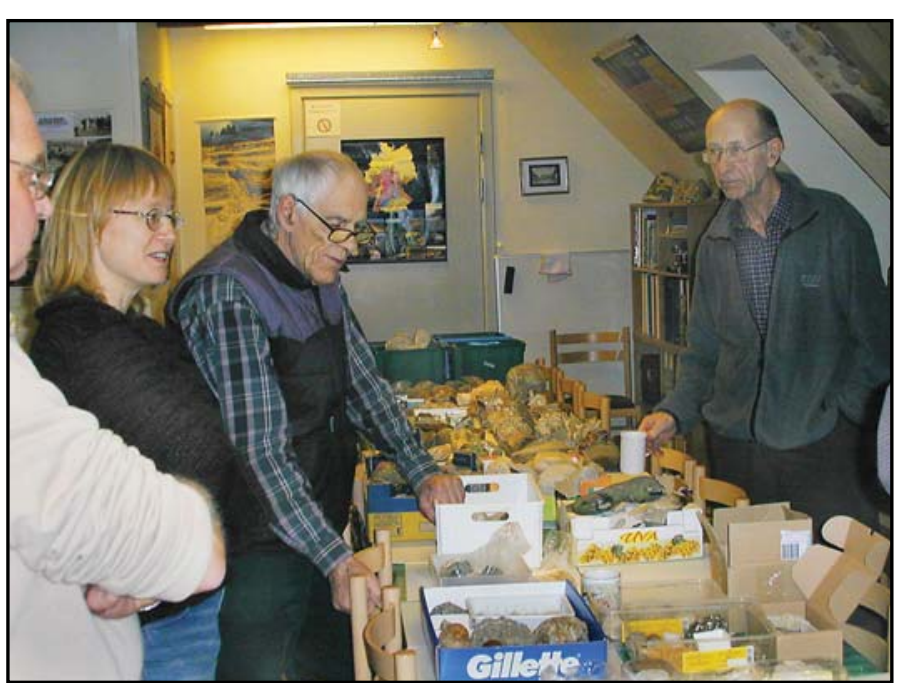

Der diskuteres ivrigt til indsamlingsaftenen . (Foto: Niels Hansen)

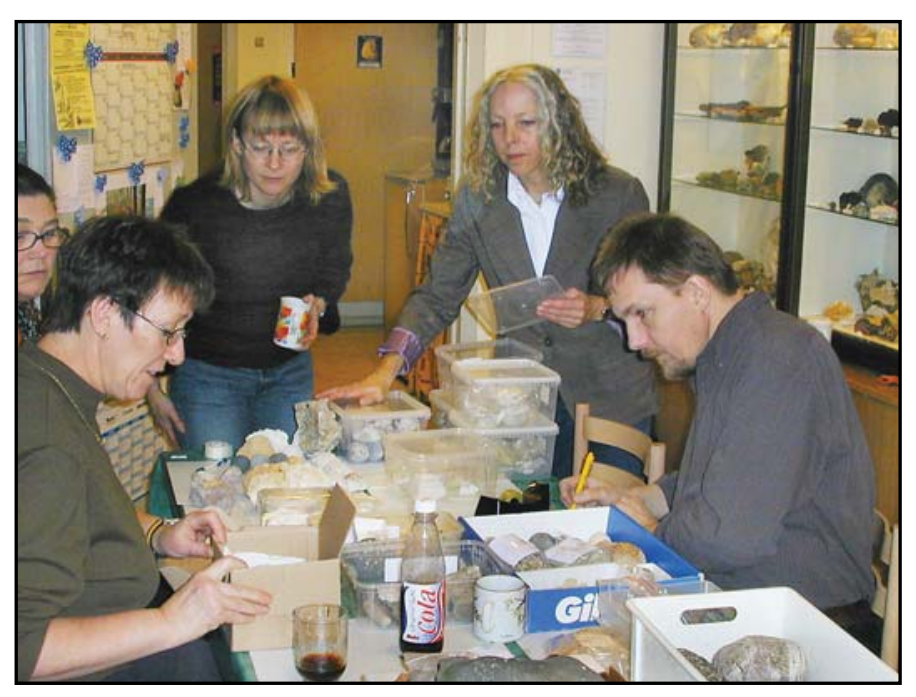

...og skrives lange lister. (Foto: Niels Hansen) 